\title{
BANK BRANCHES AS PLACES OF KNOWLEDGE CREATION: CONCEPTUAL CONSIDERATIONS AND EMPIRICAL FINDINGS AT THE MICRO-GEOGRAPHICAL SCALE
}

\author{
Franz Flögel and Hans-Martin Zademach \\ With 1 figure \\ Received 26 January $2017 \cdot$ Accepted 24 November 2017
}

\begin{abstract}
Summary: Taking recent advances on the connection of social dynamics and physical place in the geographies of knowledge creation debate as a starting point, the paper scrutinises bank branches as locations where social dynamics and physical place coincide. It presents original data gained inter alia by means of participatory observation on the credit-decision processes of both a private big bank operating nationwide and a regional savings bank in Germany. Our results first highlight the general role of physical characteristics of bank branches - most notably the arrangement in the workplace and the resulting degrees of accessibility and confidentiality - in processes of knowledge exchange and creation. In addition, our insights reveal that both bank executives and bank customers are well aware of this connection between physical characteristics and social dynamics, and thus strategically design their branches and select certain sites for negotiations.
\end{abstract}

Zusammenfassung: Neuere Arbeiten debattieren den Zusammenhang zwischen sozialen Dynamiken und physischen Orten für die Generierung und den Austausch von Wissen. Der vorliegende Beitrag nimmt diese Debatte als Ausgangspunkt, um den Wissensaustausch in Bankfilialen, als konkrete Orte, wo soziale Dynamiken stattfinden, eingehend zu untersuchen. Der Beitrag präsentiert empirische Ergebnisse, die unter anderem durch eine mehrmonatige teilnehmende Beobachtung in einer regionalen Sparkasse und Interviews mit einer deutschlandweit tätigen Großbank generiert wurden. Unsere Ergebnisse zeigen zunächst die Bedeutung baulicher Merkmale der Bankfilialen - besonders in Bezug auf die Gestaltung der Gebäude und die daraus resultierende Zugänglichkeit und Diskretion einzelner Zimmer - im Prozess des Wissensaustausches auf. Darüber hinaus deuten unsere Beobachtungen an, dass sowohl Bankmitarbeiter als auch Bankkunden diese Zusammenhänge zwischen baulichen Merkmalen und sozialen Dynamiken kennen, Bankfilialen strategisch gestalten und Orte bzw. Zimmer für Besprechungen entsprechend auswählen.

Keywords: bank branches, places of knowledge creation, micro-geography, firm finance, economic geography, Germany

\section{Introduction}

In the geography of knowledge creation and sharing debate it is now well-recognised that addressing mere geographical proximity between firms is unsatisfactory for explaining processes of cooperation and learning, and that knowledge creation derives first from the interaction of individuals, and not firms, be they co-located or distributed (e.g. Torre and Rallet 2005; Boschma 2005; IBERT 2007; RutTen 2016). In this spirit, Bathelt and Henn (2014) disclose how knowledge is created when professionals interact at temporary meetings like conferences and trade fairs. Similarly, GrabHer and IBERT (2014) show that individuals share knowledge in virtual communities where neither geographical nor relational proximities exist between members. Put differently, co-location represents neither a necessary nor a sufficient require- ment for knowledge sharing (Boschma 2005), thus the role of physical places in knowledge creation and sharing processes needs to be revisited.

To this end, RutTen (2016) proposes a new typology that links the social dynamics of knowledge creation with physical places and argues that place dynamics, i.e. the quality of places, influence knowledge creation and exchange there. If place dynamics are strong, then individuals connect markedly to specific places and knowledge sharing benefits from the quality of those places. According to Rutten (2016) and others (Beunza and STARK 2004) the micro-geography of sites, e.g., research centres, trading rooms, conference facilities, bars, restaurants, influences place dynamics. At this micro-geographical scale, social dynamics and physical place coincide when actors share and create knowledge. Taking this as the conceptual starting point, this paper deliberates on two related 
questions. First, by which physical and social qualities do sites shape knowledge sharing? Second, how are these sites entangled within broader processes of knowledge creation and innovations in an industry?

Most studies that discuss places of knowledge creation focus on co-working spaces, fab labs and other sites of open innovations (e.g. BRINKS 2012; SiHOVONEN and CNOSSEN 2015; BRINKS and SCHMidT 2015). Our paper contributes to the debate by investigating knowledge sharing in processes where confidentiality is required: banks' lending to smalland medium-sized enterprises (SMEs). We focus on the mundane sites of bank branches and discuss how bank employees and borrowers routinely create knowledge in social interactions by conducting lending decisions. The original empirical observations presented here came from a research project which compared the lending processes to SMEs of regional banks and large banks in Germany (see Flögel 2017). In Germany, more than 1,400 regional savings and cooperative banks conduct universal banking and compete directly with large banks, especially the so-called big banks, i.e., the four largest private universal banks with nationwide branch networks (GÄRTNER and FLÖGEL 2017). Together, these regional banks account for almost 50 percent of business lending, making Germany's banking system fairly decentralised in international comparison (FLÖgEL 2017). Detailed information on credit-granting processes of regional and large banks, which differ in their spatial organisation, was gained using an ethnographical approach, i.e., two months of participant observation in a savings bank and 40 expert interviews with savings and large banks as well as banking experts. In particular, the credit-granting practices of the customer advisor team for SMEs in the savings bank are compared to those of an SME team in a German big bank.

The following section elaborates on recent advances in the geography of knowledge creation debate, paying particular attention to the interplay of social dynamics and physical places. Section Three turns to the banking industry, exemplifies how banking is shaped by innovations concerning credit granting to SMEs, and discusses why physical places may still matter in modern banking. Following a method discussion in Section Four, Section Five presents our empirical insights on bank branches as sites where social dynamics of knowledge sharing coincide with physical places. Section Six concludes and discusses implications for future research.

\section{Places of knowledge creation and the micro- geographical scale}

The geography of knowledge creation and sharing debate has come to increasingly understand knowledge exchange and learning as interactive processes between individuals rather than firms (IBERT 2007). Following RutTen (2016), two equally over-simplistic perspectives explain the spatiality of knowledge creation. Firstly, territorial innovation models argue that knowledge creation is socially embedded. In these models, the social and institutional characteristics of places are regarded as key for explaining knowledge creation processes (for a comprehensive literature review, see e.g. Butzin 2013). However, there is nothing inherently geographical about particular institutions and social capital etc., e.g. common values and norms also develop in transnational communities (GRABHER and IBERT 2014). Secondly, the proximity debate views social, institutional and organisational proximity between actors as being of importance for the ability of firms and individuals to exchange knowledge (Boschma 2005). Geographical proximity is often seen as auxiliary proximity that reinforces other proximities (MATTES 2012). The critique here is that the proximity debate conflates cause and effect, or as RutTen $(2016,16)$ puts it: "proximities are outcomes of rather than inputs for social interaction and [...] social dynamics rather than proximities reduce uncertainty and resolve coordination problems".

Against this background, RUTTEN (2016) develops a new typology of knowledge creation in conversations which links the social and spatial contexts of knowledge creation. Individuals from different organisational and professional backgrounds use various media (e.g. face-to-face interactions, ICT lead distance interaction) to engage in conversations, which involves "intentional and ongoing knowledge creation between individuals [...] on a specific topic" (RutTen 2016, 5). Such knowledge creation does not provoke a specific geography, but the so-called place and distance dynamics constitute the geographies of conversations. In this reasoning, distance dynamics refer to the inclination of individuals to bridge distance to participate in knowledge creation, and strong distance dynamics are seen to provoke individuals to conduct conversations at multiple geographical locations. Place dynamics, on the other hand, refer to the connectedness of individuals to specific places. According to RUTTEN's (2016) conceptualisation, individuals strongly connect to a specific place when 
place dynamics are powerful and the conversation benefits from the quality of this place and develops there.

On the supposition that even tacit knowledge is not per se place bounded, but individuals exchange knowledge in social dynamic processes (BATHELT et al. 2004; Torre and Rallet 2005; IBERT 2007; Bathelt and Henn 2014; ButZin and Widmaier 2016), strong place dynamics cannot be explained with reference to accessing localised knowledge. On a regional scale, knowledge creation may be localised when individuals cluster around specific problems and challenges, e.g. region-specific issues. The dependency on researcher facilities and other physical infrastructure also localises conversations in certain regions. Furthermore, Bathelt et al. (2004) argue that the quality of local buzz makes certain regions more attractive/supportive for conversations than others; in other words: the more diverse and dynamic the place, the more local buzz is likely to occur, supporting knowledge creation there (FLORIDA 2002; RUTTEN 2016).

As face-to-face interactions continue to be important for knowledge creation (TORRE and RALLET 2005; Bathelt and Henn 2014), actual meeting sites like conference venues, research facilities, buildings and offices matter. The fact that social dynamics coincide with physical places at these sites suggests that knowledge creation happens on a more micro-geographical scale than that of cities or regions (Ibert 2007; Grandadam et al. 2013; RutTen 2016). Supportive amenities tend to encourage knowledge creation there. Yet, as RUTTEN (2016) argues, a supportive environment is not a result of the pure physical characteristics of amenities but a dynamic outcome shaped by the physical conditions and social interaction at the sites. To understand the interplay of physical characteristics and social dynamics which makes some places more appropriate for knowledge sharing than others, it is worth studying these actual sites of knowledge creation, which implies analysing the micro-geographical scale.

In the management literature it is taken for granted that bringing people together, e.g., co-locating them in an office and creating places of interaction, supports the sharing of knowledge among them (e.g. LEvin et al. 2002). This effect of shared workplaces is also identified by the communities of practice literature (VAN WEELE et al. 2017). However, detailed discussions of the possibly diverse effects of micro-geography on knowledge creation are missing. In the creative city / neighbourhood development debate the attractiveness of certain buildings for cre- ative individuals has long been recognised (LANDRY 2000; FlORIDA 2002). Loose spaces, temporarily occupied buildings or co-working spaces flexibly link individuals and can stimulate new ideas and projects (Franck and Stevens 2006; Merkel 2012; Brinks 2012; Sinovonen and Cnossen 2015). For example, the aim of innovation and creativity labs is to mingle diverse professions to stimulate the creation of knowledge (BRINKS and SCHMIDT 2015). Empirical studies show that (business) ideas and new projects develop around vacant buildings, i.e. are stimulated by the buildings (FLÖgEL and GärTNER 2011; Sinovonen and CNossen 2015). For example, the availability and spatial dimension of a shop triggered the founding and shaped the activities of a social enterprise (FlÖGEL and GärTNer 2011).

But also, unspectacular sites and even non-places (Augé 1994) become important venues for knowledge exchange (McNeill 2009). For example, A. Growe and C. Mager demonstrate in an as yet unpublished paper that business consultants use pragmatic sites like airport bars to conveniently conduct short faceto-face meetings. On the other hand, they meet at special (e.g. remote) sites that support freedom for new ideas and focused discussions. These findings indicate that actors are well aware of the impact of places on knowledge creation and tactically select meeting sites to influence meeting outcomes.

\section{Bank branches and the changing spatiali- ties of knowledge creation in SME lending}

Like no other industry, the banking industry stands for shifting spatialities of knowledge creation caused by major innovations (O'BRIEN 1992). For high finance, the rise of connectivity by information and communication technologies (KNORR CETINA and BRugGer 2004) and the rise of quantitative finance - mathematical models, formulae, algorithm - (MacKenzie and Millo 2003; MacKenzie 2006) are debated. Whereas these developments suggest the importance of personal interactions and geographical proximity is diminishing, the effects are actually more nuanced. To take a striking example, the speed sensitivity of high-frequency trading makes geographical proximity between the servers of traders and stock exchanges crucial, ensuring information is obtained milliseconds earlier than competitors (Zook and Grote 2016). But also personal interactions gain new importance because of the ICT-induced ubiquitous availability of codified information (Lo 2003; Beunza and Starke 2004; Zademach 2009). 
For example, Lo (2003) shows that only personal contacts and private information allow actors to stand out from competitors and gain competitive advantages in the Merge \& Acquisition market. Lo's (2003) study indicates that geographical proximity still matters as it facilitates socially embedded interactions and hence access to such information. BEUNZA and STARKE $(2004,5)$ advance a similar conclusion: "[...] after months of fieldwork, we realized that, as increasingly more information is almost instantaneously available to nearly every market actor, the more strategic advantage shifts from economies of information to socio-cognitive process of interpretation". BEUNZA and STARKE's (2004) ethnography highlights the micro-geographical scale and argues that geographical proximity between diverse teams in the trading room supports traders in recognising earning opportunities and identifying unexpected risks. Hence, micro-geographical proximity supports the creation of new knowledge, e.g. a new arbitrage trade, as diverse teams can easily cooperate and share knowledge. Furthermore, the observed trading room manager was aware of the advantages of proximity and rotated his employees to stimulate communication among teams and avoid demarcations.

Concerning SME finance, banks have been seen to create and share knowledge about the borrowing firms and their markets through personal interaction (UzZI and LanCASTER 2003; Kalthoff 2003; HandKe 2011; Flögel 2017). This inter- (with clients, external experts, other banks etc.) and intra-organisational (supervisors, credit officers etc.) interaction becomes necessary because one key function of banks is to mitigate information asymmetries between savers and borrowers in order to conduct lending decisions (Diamond 1984; KLAGGE 2009; ZADEMACH 2014). Furthermore, banking regulation requires a separation of functions in the organisation of lending processes (BAFIN 2012), so at least two bank employees must approve lending decisions for risky credits. Against this background, SME lending decisions of banks are understood as organised knowledge creation processes in which several individuals from different organisations interact and negotiate credit decisions.

To be clear, banks do not pursue radical innovation when lending to SMEs. However, banks indeed create knowledge in the "knowledge as object" and "knowing in practice" understanding of the term (IBERT 2007). "Knowledge as object" in the sense that by screening and monitoring, banks "discover" the creditworthiness of firms and codify the results in credit applications and by developing tailored fi- nancial solutions (see also HANDKE 2011). "Knowing in practice" because conducting lending decisions to risky borrowers involves social practices of negotiations between banks and borrowers as well as bank internally. In positive lending decisions, a compromise is achieved with which all involved actors "can live". However, banks' lending decisions differ from conversations (open innovation processes), as they are not open and ongoing. Instead, the usual standards in the industry, most notably bank secrecy (or privacy), i.e. the common requirement that prohibits banks from spreading information about their clients, restricts the spread of information. However, bank secrecy facilitates knowledge exchange and creation in banking because firms can reveal private knowledge to their bank and must not fear its diffusion to competitors, customers and suppliers (AlLEN and Gale 2000). Hence, knowledge creation in banking occurs in a distinct tension between knowledge sharing and confidentiality.

Conversations influence knowledge creation in SME lending indirectly. The banking industry is constantly shaped by conversations regarding banking regulation, new (ICT) technologies, new products, risk management methods, accounting standards, development of sectors, economic outlook, central bank policy etc. To give an example, SME rating systems developed from private credit scoring (which was in use as early as the 1950s) and spreadsheet software used to analyse borrowers' financial statements (UDELL 2009). In the 1990s several German savings banks developed and utilised more or less advanced SME rating systems on a voluntary basis, sometimes cooperatively (rating provider of the savings banks, 30 May 2013, interview). At the same time, the international conversation on banking regulation advanced the idea of accurately determining the risk of all bank assets, which implies the rating of SME credits. This conversation eventually led to the Basel II recommendations that were implemented in 2007 (PAul 2011). At a national scale, the so-called Mindestanforderungen an das Kreditgeschäft der Kreditinstitute $(\mathrm{MaK})$ regulation was debated in the 1990s and came into power in 2004. MaK promoted the application of rating for SMEs. As all banking associations participated in this regulatory conversation, it in turn powered the internal conversation of the savings banks financial group concerning the common development and implementation of an SME rating system (rating provider of the savings banks, 30 May 2013, interview). The SME rating system was developed and tested by selected savings banks in the late 1990s and rolled out for obligatory 
use in the over 400 German savings banks in 2002. This rollout marked a profound change in the SME credit granting praxis of savings banks.

As seen in the rating system example, conversations influence (the geographies of) lending by shaping the way in which banks conduct lending decisions. As all banks use rating systems for SME lending, the question of which role geographical distance plays in lending gains importance. If the rating scores completely determined lending to SMEs, then personal interactions (in the local branches) would hardly matter for lending decisions anymore. Because of this relation, rating systems must be considered to enable an understanding of banks' geographies of knowledge creation (LEYSHON and THRIFT 1999; GÄrTNER and Flögel 2013). Correspondingly, researchers must question the often taken-for-granted view that regional banks "naturally" conduct lending decisions at a shorter geographical distance to SMEs than large banks, and in doing so, conduct superior screening.

Turning to the place in question, bank branches, against the background of the above - especially the widespread application of rating systems for risk analyses, it is well recognised that knowledge creation in the branch has decreased (LEYSHON and Thrift 1999; Leyshon and Pollard 2000; Mason 2010). For example, local branch managers in the United Kingdom used to have substantial discretion in lending to business clients and were involved in local networks to gain knowledge about clients and markets in the 1990s. In contrast, nowadays, branches and their managers tend to be one channel among others (telephone, internet) that sells standardised products by following fixed lending criteria (VIK 2016). As demonstrated in Section 5.1, local customer advisors of the case-study savings bank and big bank execute substantial discretion in lending and are one key actor in charge of screening and monitoring business clients. Therefore, the micro-geography of bank branches and the social dynamics of knowledge creation taking place there are able to influence lending decisions.

Few studies have addressed the physical characteristics of bank branches directly. Survey results on private clients of commercial banks in Germany indicate that the willingness of customer advisors to help and the individual attention given to clients are strongly associated with customer satisfaction. The physical appearance of the branches was unimportant on this dimension, but influences the inclination of clients to recommend the bank (Yavas et al. 2004). Overall, little is known about the interaction of social dynamics and physical characteristics in knowledge creation for lending decisions at the sites of bank branches.

\section{Methods and in-depth studied banks}

An ethnographic approach was applied to gain detailed insights into banks' lending process organisation, the interaction between the actors involved in lending and its effects on knowledge creation for lending decisions. In particular, the first author completed a two-month, full-time student internship in different departments (SME customer advisor team, the back office and the bank control department) of the savings bank. The purpose of the internship was known to the employees of the savings bank but unknown to clients. Additionally, 40 interviews with experts from five large banks (of which one is studied in depth), four regional savings and cooperative banks and related organisations, i.e., banking associations and business consultancies, provide a broader picture of banks' lending to SMEs. Obtaining sufficient reliable information was a sensitive topic because banks consider their credit decision and risk assessment processes to be commercially sensitive and the abovementioned bank secrecy regulations prohibit the dissemination of information about clients. Assurance of anonymity and the confidentiality agreement in the internship contract enabled intimate insights at the price of ensuring confidentiality in presenting the data.

Because the customer segments and regional banking market conditions influence banks' lending process organisation and patterns it was crucial to keep both constant for the in-depth comparison. Therefore, the observed savings bank was compared with the SME customer advisor team of one of the four German big banks. Here, six interviews with customer advisors and supervisors were conducted. The team operates in a branch located in the same region as the savings bank and competes for the same clients, i.e. firms were observed that have loans from both banks (savings bank, 28 November 2013, protocol). Clients are rather small SMEs, i.e., those with revenues from $€ 500,000$ to $€ 10$ million and total business credit between $€ 100,000$ and $€ 5$ million. The studied region is economically rather weak with unemployment rates above the national level.

The interviews were taped and transcribed; participant observations were recorded in 41 daily protocols written on each day of observation. In the two-stage qualitative data analyses (inductive-deduc- 
tive), interviews and protocols were examined using the MaxQDA 11 software package. Because this paper compares detailed results from participant observation over 41 working days (during which we conducted numerus ad-hoc interviews) with findings from expert interviews, the level of detail and reliability of results are lower for the big bank. Despite many attempts, it proved impossible to conduct participant observation in a suitable big bank. The big bank studied in depth was interviewed before and after participant observation in the savings bank. Especially the two interviews conducted following the participant observation permitted contrasts with the insights gained in the savings bank.

\section{Bank branches as places of social interaction and knowledge creation: Empirical results}

This section presents our empirical insights on bank branches as particular places where the social dynamics of knowledge creation coincide with physical characteristics. It illustrates to what extent physical characteristics influence the way in which individuals interact. To clarify the possible influence that branches and their employees can have on lending (in line with the second research question of this paper), Section 5.1 demonstrates the role of the branches in the broader process of lending decision making. Section 5.2 then turns to the micro-geographical scale. It discusses two characteristics, accessibility and confidentiality, as factors with a distinct impact on processes of knowledge creation in the particular context of our study, i.e. the interaction of customer advisors and customers in banks' lending to SMEs.

\subsection{Lending process organisation and knowl- edge creation}

Our empirical findings first unveil a range of pronounced differences between the two types of investigated banks - most notably the degree of integration of rating systems, the distance between the bank employees involved in the credit decisions, and their decision-making power - that result in varying geographies of credit decisions to SMEs. Whereas the savings bank investigated defines no strict rating score cut-off limit and CEOs execute unrestricted credit-granting power, the big bank investigated irrevocably rejected credit requests from SMEs with poor rating scores. In case of medium rating scores, a centralised back officer team decides on the credit application. It is the job of the big bank's local customer advisors "to convince the back office", though communication is restricted to e-mails and (rare) telephone calls because of the organisational and geographical distance to the back office (big bank, 11 February 2014, interview). In contrast, the savings bank involves supervisors and back officers even for less risky lending decisions, but organisationally and socially embeds the customer advisors and supervisors (in the branches) with the back office and high-level supervisors (in the headquarters). This implies that every customer advisor has a designated credit officer in the headquarters and that personal communication with credit officers and high-level supervisors, including CEOs, is usual (e.g., we observed daily communication with credit officers) (savings bank, 19 and 25 November 2013, protocols).

As argued in FLÖGEL (2017), short distances between customer advisors and decision makers in the savings bank encourages advisors to collect detailed information and create profound client knowledge, as they are able to communicate knowledge up the hierarchy and influence lending decisions. In the big bank, however, long distances to credit officers reduces the incentive of customer advisors to create client knowledge in cases of medium rating scores, and stifles it altogether in cases with poor rating scores because of the inevitable rejection of new credits. Still, customer advisors in the big bank's branches influence credit granting by negotiation with credit officers in case of medium rating scores and because they always execute the right of initial rejection. Similarly, customer advisors of the studied savings bank execute this right, i.e., they decide whether to process a client's credit request by compiling a credit application.

To lend, bank employees of the savings bank and the big bank must compile written credit applications justifying the lending decision. This requires extensive information, like firm's financial statements and account balances. Compiling a credit application is expensive and time-consuming; consequently, most customer advisors ensure in advance that the credit application will be favourably received (big bank, 9 September 2013, interview). Nonetheless, customer advisors of the savings bank only discuss a very small share of all credit applications with the decision makers (savings bank, 10 December 2013, protocol). This observation is explained by the fact that experienced customer advisors usually know in advance which credit requests will be approved, i.e. they predict the outcome of credit decision processes. In other words, they are able to complete the complex task without an in-depth analysis, they know in practice. 
For the (few) in-between lending decisions (credit requests with uncertain outcomes), the bank employees from the savings bank studied usually conduct extended telephone and face-to-face discussions. For example, the customer advisors hold extensive negotiations with the borrowers and negotiate possibilities for credit granting with supervisors and credit officers. At these interactions, bank employees negotiate meanings and constitute whether an SME is creditworthy or not (savings bank, 2 December 2013, protocol). Participant observation demonstrated that the whole breadth of knowledge of customer advisors is exchanged with supervisors in this negotiation, including, for example, detailed knowledge on clients' private affairs, information from local networks and gut feeling (savings bank, 3 and 19 December 2013, protocols). We now turn to bank branches as one place where such knowledge is gained in interactions between customer advisors and clients.

\subsection{Accessibility and confidentiality as factors of knowledge exchange and creation}

Participant observation revealed that the SME customers very frequently communicate spontaneously with their customer advisors at the savings bank, i.e. they call or just pop into customer advisors' offices for minor interactions. In contrast to these communication patterns, the customer advisors of the big bank visit customers more often at their business sites to conduct scheduled face-to-face meetings. The micro-geographical design of the two branches supports this difference in personal communication. Customer advisors are very accessible in the savings bank, whereas entrance barriers exist in the branch of the big bank.

Two constructional features cause the high accessibility of the savings bank's customer advisors for their customers (see Fig. 1). Firstly, all office doors to the second floor of the counter hall remain unlocked and customers can easily access the second floor via a large freestanding staircase in the middle of the counter hall. Therefore, well aware of the accessibility, existing customers very frequently drop by unannounced. The only exception to this rule is the team leader's office that customers can only access through the team assistant's office. Secondly, the offices open onto the busy main street and are visible from the outside through a large glass front. Curtains provide some privacy but, nonetheless, customers can see at a glance from the street if their customer advisor is at her or his desk.
Similar to the savings bank, the SME customer advisor team of the big bank in question occupies the second floor of a branch where other teams also work (e.g. a private customer team) (Fig. 1: right). The team leader is shielded from the other offices by his assistant's office. Striking differences in the accessibility became visible at the interview appointments. Visitors cannot access the corporate customer team without previous registration at the counter, as the door to the second floor is locked. Hence, visitors approach the counter and service staff here call the customer advisors, only directing visitors to the second floor if the customer advisors confirm the meeting. This constructional and organisational feature prevents customers from popping into customer advisors' offices without announcement. In fact, customer advisors even have the possibility to hide, as they only have to instruct service staff to pretend they are out of the office.

The participant observation at the savings bank indicates that personal communication with customers is not always desirable from a bank employee's point of view. Reasons to avoid personal interactions include:

- No interest in new business with certain customers. For example, one manager had performed badly in a property development project financed by the savings bank. When this manager called to ask his customer advisor for a loan to develop new property, the advisor was very reserved and requested many additional documents instead of arranging a personal meeting. The customer advisor indicated that she would be happy if the customer asked another bank to finance his project, but she was also reluctant to reject him harshly due to concerns about compromising the existing loan contracts (savings bank, 2 December 2013, protocol).

- No interest in the renegotiation of existing contracts. Personal negotiations with customers become emotional from time to time and always carry the risk of an uncertain outcome. Customer advisors therefore sometimes prefer avoiding personal encounters to prevent unpleasant verbal conflicts and to render it less likely that they give in to the demands of the customers (savings bank, 10 December 2013, protocol). This observation indicates that personal negotiations in fact imply uncertain outcomes and can change action, i.e. create new knowledge.

- Time constraints. Sometimes the bank employees have not yet made an internal decision on how to act, or currently lack the time to interact with customers (savings bank, 13 December 2013, protocol). 


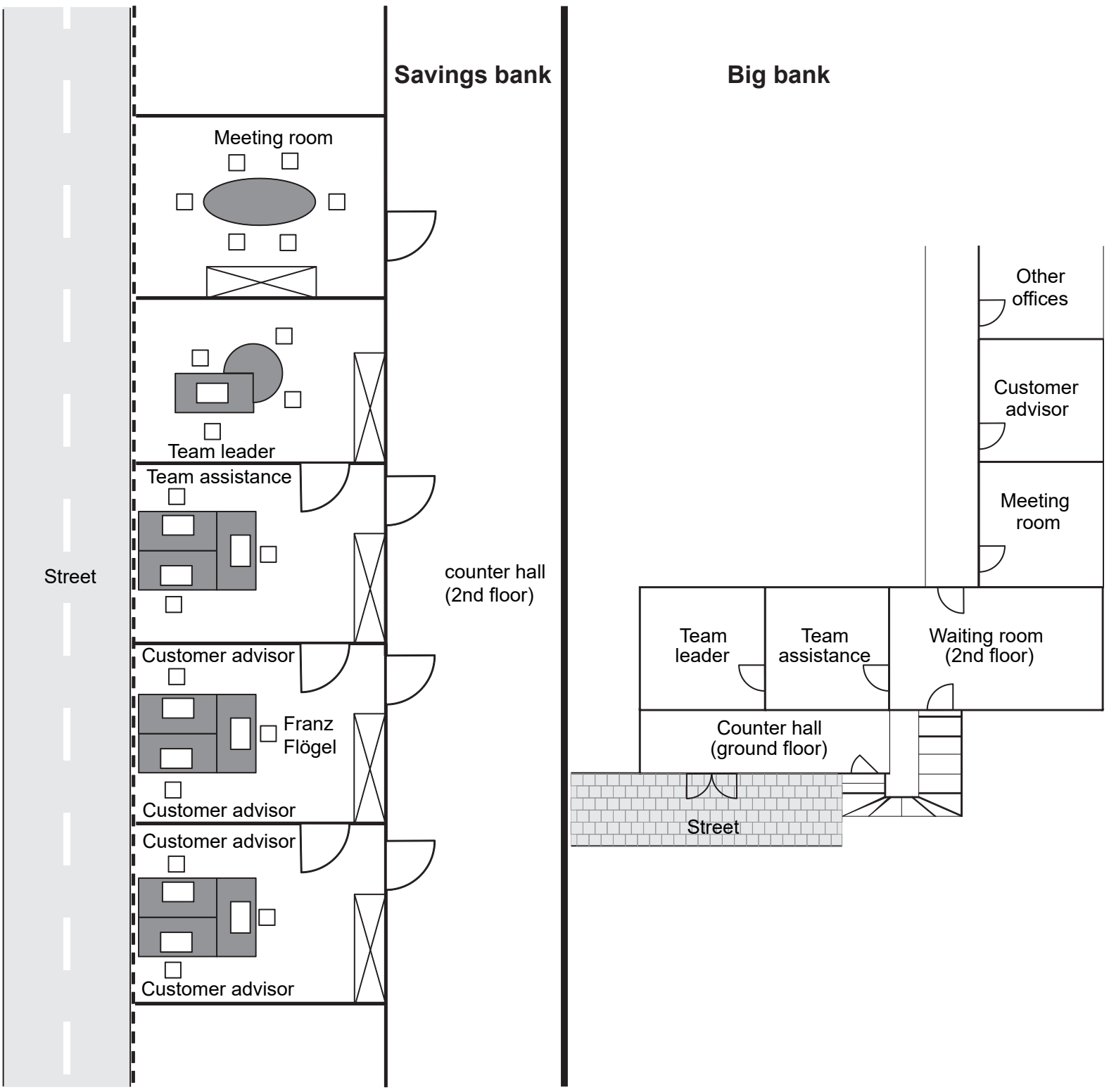

Fig. 1: Outline of the offices of the savings bank's and the big bank's SME customer advisor teams under study

The customer advisors of the savings bank can only avoid personal encounters to a certain degree, e.g. in the case of telephone calls (savings bank, 4 December 2013, protocol), because of the micro-geographical layout of their branch. Often customers just pop into the offices (without prior announcement) and consequently make the customer advisors interact with them, forcing them to take a position. This micro-geographical accessibility turns out to be a relevant aspect of the relationship between the customer advisor and SME customer. It restricts the ability of customer advisors to ignore customer de- mands and may lead to more decisions in favour of the customers, as bank employees have to consider the possibility of personal interactions with their clients. Against the background of the observation that customer advisors dislike communicating negative decisions to their customers face-to-face, the inaccessibility of customer advisors in the big bank sticks out as they have the ability to avoid spontaneous personal interaction.

As discussed, the architectural layout of the savings bank branch limits the feasibility of tactics to avoid spontaneous face-to-face interactions. 
Nevertheless, customer advisors try to manage the length and topics of meetings with their selection of rooms. For instance, on one occasion a customer called and wanted to hand in his annual financial statements just before closing time. His customer advisor was not pleased because the client was known to be talkative. The team joked that the customer advisor should avoid a talk in the meeting room because that would extend the discussion. In order to keep the interaction short, the customer advisor received her customer in the counter hall. To the surprise of all colleagues, she was quickly back in the office (savings bank, 13 December 2013, protocol).

Directing customers to the meeting room - and offering coffee, tea and biscuits - is an important tactic to extend the length of the meetings. Similarly, the team leader closes her office door when she wants to conduct extensive discussions with customers (her office contains a round table for meetings). Such selection tactics also influence the topic of the talks because customer advisors can address critical and sensitive topics within the confidential environment of a meeting room; the lack of seclusion in an office shared by multiple customer advisors is less conducive for such topics.

Certain customers are aware of these placing tactics. For example, one managing owner had very frequent interactions with his customer advisor at the time of observation because of the stressed liquidity situation of his firm. So, he often visited his customer advisor with several transfer slips and they negotiated the order and conditions of transactions in her shared office (savings bank, 3 December 2013, proto$\mathrm{col})$. They managed to find a solution for the liquidity shortage on a day-to-day basis. Nevertheless, the customer advisor wanted a long-term solution as she feared that if the customer could not pay an important supplier or conveyance, for instance, his firm would be at risk as important buyers or suppliers would break off business relations (savings bank, 19 December 2013, protocol). She therefore wanted to discuss the problem in the meeting room, hoping to push the managing owner to spend less money and compile a strict liquidity plan. However, the owner refused to enter the meeting room, well aware that critical topics would be addressed there. The shared office of the customer advisor was barely suitable to address such critical topics because of the presence of other customer advisors, ringing telephones, the risk that other customers might pop in and not least the presence of a trainee. It hence becomes clear that the confidentiality of sites represents another characteristic of places that influences knowledge exchange and creation there.

\section{Conclusion}

The actual places of knowledge creation are increasingly becoming the focus of the knowledge creation debate. As the social dynamics of knowledge creation between individuals take place on smaller geographical scales than cities and regions, the micro-geographies of the very sites of knowledge creation - conference venues, offices, restaurants etc. - matter. Most studies on the micro-geography of sites focus on co-working spaces, fab labs and other sites of open innovation, and deliberate on the possibilities to bring diverse knowledge and new ideas together. This paper contributes to the debate by looking at a mundane place where knowledge is created on a routine basis: bank branches. The screening and monitoring of borrowers conducted there cannot be viewed as an open conversation; it is rather the case that knowledge creation in lending happens between the poles of bank confidentiality and knowledge sharing. Putting bank branches centre stage, this paper indicates the diverse effects sites have on processes of knowledge creation in which the risk of leaking knowledge can also hinder its sharing.

Building on the empirical comparison of a regional savings bank and a big bank in Germany, the presented research has identified two particularly salient characteristics that influence knowledge creation in bank branches. Regarding the first, accessibility, the empirical observation indicates that the mere chance of a personal encounter with customers tends to impact on the behaviour of bank employees. Secondly, our results propose confidentiality as a notable aspect, at least in the context of the banking business. Busy sites, like shared offices, prevent intensive discussions and restrict the possibility of addressing confidential and critical/conflictual topics, whereas meeting rooms and private offices prove suitable for these kinds of negotiations. Both customer advisors and the customers observed were aware of these effects and selected sites for negotiation accordingly. Accessibility and confidentiality are thus two relevant categories that deserve further attention in contemporary conceptualisations of the micro-geographies of knowledge creation.

In his above introduced conceptualisation of the social-spatial dynamics of knowledge creation, RUTTEN (2016) emphasises that it is not the physical characteristics of a place in itself that influence knowledge creation, but the coincidences of physical places and social dynamics. This consideration corresponds well with our empirical results, such as, for instance, the observation that the combination 
of both - unlocked office doors and the fact that a range of customers are aware of this situation constitutes our finding that shared offices are unsuitable places for the discussion of critical topics. Notably, our two identified characteristics of places correspond with two attributes which make actors trustworthy according to the findings of LEviN et al. (2002: 4): availability (does he or she have time and give attention to clients?) and discretion (does he or she respect client confidentiality?). Therefore, our findings suggest that banks and other organisations that want to appear trustworthy to their customers should design branches accordingly. Such designs tend to cause more attention to client needs (which improve customer satisfaction according to Yavas et al. 2004) and may lead to more decisions in favour of the clients, if the employees in the branches possess discretion, i.e. execute lending authority or are able to influence decision makers.

On a more general level, our findings have shown that participant observation is a promising method to study the influence of sites on knowledge creation. Further research applying this method therefore appears particularly likely to advance understanding of the interplay of social dynamics and physical places in knowledge creation at the micro-geographical scale. However, the sites of knowledge creation should be studied in the context of broader processes of knowledge creation. Therefore, conducting ethnographies at multiple sites appears suitable.

\section{Acknowledgements}

The authors gratefully acknowledge the financial support of the scholarship by the Studienstiftung des Deutschen Volkes. In addition, they wish to thank all executives interviewed or observed for the time they devoted to the project. We also thank the participants of the 'Forschungswerkstatt Finanzgeographie' in Münster and the symposium 'revival of places' in Hannover 2014, in addition to the two anonymous reviewers for their valuable comments on earlier versions of the paper. The usual disclaimers apply.

\section{References}

Allen, F. and Gale, D. (2000): Comparing financial systems. Cambridge.

Augé, M. (1994): Orte und Nicht-Orte. Vorüberlegungen zu einer Ethnologie der Einsamkeit. Frankfurt.
BAFIN (Bundesanstalt für Finanzdienstleistungsaufsicht) (2012): Mindestanforderungen an das Risikomanagement MaRisk. Rundschreiben 10/2012 (BA).

Bathelt, H. and Henn, S. (2014): The geographies of knowledge transfers over distance: toward a typology. In: Environment and Planning A 46 (6), 1403-1424. https://doi.org/10.1068/a46115

Bathelt, H.; Malmberg, A. and Maskell P. (2004): Clusters and knowledge: local buzz, global pipelines and the process of knowledge creation. In: Progress in Human Geography 28 (1), 31-56. https://doi. org/10.1191/0309132504ph469oa

Beunza, D., and Stark, D. (2004): Tools of the trade: the socio-technology of arbitrage in a Wall Street trading room. In: Industrial and corporate change 13 (2), 369400. https://doi.org/10.1093/icc/dth015

Boschma, R. (2005): Proximity and innovation: a critical assessment. In: Regional Studies 39 (1), 61-74. https:// doi.org/10.1080/0034340052000320887

BRINKs, V. (2012): Netzwerke(n) und Nestwärme im Coworking Space. Arbeiten zwischen Digitalisierung und Re-Lokalisierung. In: Geographische Zeitschrift, 100 (3), 129-145.

BRINKS, V. and Schmidt, S. (2015): Global knowledge communities in temporary spaces. Working paper. https:// www.sheffield.ac.uk/polopoly_fs/1.452220!/file/ BrinksSchmidt.pdf (Date 19.01.2017).

Butzin, A. (2013): Knowledge dynamics in innovation biographies. A methodological and spatial perspective. Marburg.

Butzin, A. and Widmaier, B. (2016): Exploring territorial knowledge dynamics through innovation biographies. In: Regional Studies 50 (2), 220-232. https://doi.org/1 0.1080/00343404.2014.1001353

DiAmOND, D. (1984): Financial intermediation and delegated monitoring. In: Review of Economic Studies LI, 393414. https://doi.org/10.2307/2297430

FLöGEL, F. (2017): Distance and modern banks' lending to SMEs: ethnographic insights from a comparison of regional and large banks in Germany. In: Journal of Economic Geography July 2017. https://doi.org/10.1093/jeg/lbx017

Flögel, F. and GÄrTnER, S. (2011): Raumunternehmen. Endbericht an die Montag Stiftung Urbane Räume. Bonn. www.iat.eu/files/raumunternehmen.pdf (Date 25.01.2017).

FLORIDA, R. (2002): The rise of the creative class: and how it's transforming work, leisure, community and everyday life. New York.

Franck, K. A. and Stevens, Q. (eds.) (2006): Loose space: possibility and diversity in urban life. London.

GÄrtner, S. and FlöGel, F. (2013): Dezentrale versus zentrale Bankensysteme? Geographische Marktorientierung und Ort der Entscheidungsfindung als Dimensionen 
zur Unterteilung von Bankensystemen. In: Zeitschrift für Wirtschaftsgeographie 57 (3), 34-50. https://doi. org/10.1515/zfw.2013.000

Gärtner, S. and Flögel, F. (2017): Raum und Banken. Zur Funktionsweise regionaler Banken. Baden-Bande.

Grabher, G. and Ibert, O. (2014): Distance as asset? Knowledge collaboration in hybrid virtual communities. In: Journal of Economic Geography 14 (1), 97123. https://doi.org/10.1093/jeg/lbt014

Grandadam, D.; Cohendet, P. and Simon, L. (2013): Places, spaces and the dynamics of creativity. The video game industry in Montreal. In: Regional Studies 47 (10), 17011714. https://doi.org/10.1080/00343404.2012.699191

HandKe, M. (2011): Die Hausbankbeziehung. Institutionalisierte Finanzlösungen für kleine und mittlere Unternehmen in räumlicher Perspektive. Berlin.

IBERT, O. (2007): Towards a geography of knowledge creation. The ambivalences between 'knowledge as an object' and 'knowing in practice'. In Regional Studies 41 (1), 103-114. https://doi. org/10.1080/00343400601120346

Kalthoff, H. (2003): Zahlenwelten. Studien zur epistemischen Ordnung der Bankenwirtschaft. Habilitationsschrift.

KLAGge, B. (2009): Finanzmärkte, Unternehmensfinanzierung und die aktuelle Finanzkrise. In: Zeitschrift für Wirtschaftsgeographie 53 (1-2), 1-13. https://doi. org/10.1515/zfw.2009.0001

Knorr Cetina, K. and Bruegger, U. (2004): Traders' engagement with markets: a postsocial relationship. In: Amin, A. and Thrift, N. (eds.): Cultural economy reader. Oxford, 121-143.

LANDRY, C. (2000): The creative city: a toolkit for urban innovation. London.

Levin, D. Z.; Cross, R.; Abrams, L. C. and Lesser, E. L. (2002): Trust and knowledge sharing: a critical combination. IBM Institute for Knowledge-Based Organizations. Somers.

Leyshon, A. and Pollard, J. (2000): Geographies of industrial convergence: the case of retail banking. In: Transactions of the Institute of British Geographers 25 (2), 203-220. https://doi.org/10.1111/j.00202754.2000.00203.x

Leyshon, A. and Thrift, N. (1999): Lists come alive: eletronic systems of knowledge and the rise of credit-scoring in retail banking. Economy and Society, 28 (3), 434-466. https://doi.org/10.1080/03085149900000013

Lo, V. (2003): Wissensbasierte Netzwerke im Finanzsektor. Das Beispiel des Mergers \& Acquisitions-Geschäfts. Wiesbaden. https://doi.org/10.1007/978-3-322-81588-0

MacKenzie, D. A. (2006): An engine, not a camera. How financial models shape markets. Cambridge, Mass. https:/ / doi.org/10.7551/mitpress/9780262134606.001.0001
MacKenzie, D. A. and Millo, Y. (2003): Constructing a market, performing theory: the historical sociology of a financial derivatives exchange. In: The American Journal of Sociology 109, 107-145. https://doi.org/10.1086/374404

Mason, C. (2010): Editorial introduction. Entrepreneurial finance in a regional economy: the case of Scotland. In: Venture Capital 12, 167-172. https://doi.org/10.1080/1 3691066.2010.507033

Mattes, J. (2012): Dimensions of proximity and knowledge bases: innovation between spatial and non-spatial factors. In: Regional Studies 46 (8), 1085-1099. https: / / doi.org/1 $0.1080 / 00343404.2011 .552493$

McNeILl, D. (2009): The airport hotel as business space. In: Geografiska Annaler Series B: Human Geography 91, 219_ 117. https://doi.org/10.1111/j.1468-0467.2009.00316.x

Merkel, J. (2012): Auf der Suche nach Austausch: Digitale Nomaden und Coworking Spaces. In: WZB Mitteilungen 136, 15-17.

O'Brien, R. (1992): Global financial integration. The end of geography. New York.

Paul, S. (2011): Umbruch der Bankenregulierung: Die Entwicklung des Baseler Regelwerks im Überblick. In: HofMANN, G. (ed.): Basel III und MaRisk. Frankfurt am Main, $9-64$.

Rutten, R. (2016): Beyond proximities. The socio-spatial dynamics of knowledge creation. In: Progress in Human Geography 41 (2), 159-177. https://doi. org/10.1177/0309132516629003

Sihovonen, T. and Cnossen, B. (2015): Not only a workplace. Reshaping creative work and urban space. In: Observatorio (OBS*) Journal. http://obs.obercom.pt/index.php/ obs/article/view/973 (Date 29.11.2017).

Torre, A. and Rallet, A. (2005): Proximity and localization. In: Regional Studies 39 (1), 47-59. https://doi. org/10.1080/0034340052000320842

UdELL, G. F. (2009): Financial innovation, organizations, and small business lending. In: Alessandrini, P.; Fratianni, M. and ZazZAro, A. (eds.): The changing geography of banking and finance. New York, 15-26. https://doi. org/10.1007/978-0-387-98078-2_2

Uzzi, B. and Lancaster, R. (2003): Relational embeddedness and learning: the case of bank loan managers and their clients. In: Management Science 49 (4), 373-399. https: / doi.org/10.1287/mnsc.49.4.383.14427

Van Weele, M.; Steinz, H. J. and van Rijnsoever, F. J. (2017): Start-up communities as communities of practice: shining a light on geographical scale and membership. In: Tijdschrift voor Economische en Sociale Geografie, July 2017. https:/ / doi.org/10.1111/tesg.12277

VIK, P. (2016): 'The computer says no': the demise of the traditional bank manager and the depersonalisation of British banking, 1960-2010. In: Business History 59 (2), 231-249. https://doi.org/10.1080/00076791.2016.1177024 
Yavas, U.; Benkenstein, M. and Stuhldreier, U. (2004): Relationships between service quality and behavioral outcomes: a study of private bank customers in Germany. In: International Journal of Bank Marketing 22 (2), 144 157. https://doi.org/10.1108/02652320410521737

Zademach, H.-M. (2009): Global finance and the development of regional clusters: tracing paths in Munich's film and TV industry. In: Journal of Economic Geography 9 (5), 697-772. https://doi.org/10.1093/jeg/lbp029

Zademach, H.-M. (2014): Finanzgeographie. Darmstadt.

Zook, M. and Grote, M. (2016): The microgeographies of global finance: high frequency trading and the construction of information inequality. In: Environment and Planning A 49 (1), 121-140. https://doi. org $/ 10.1177 / 0308518 \times 16667298$

\section{Authors}

Dr. Franz Flögel

Institute for Work and Technology Westfälische Hochschule Gelsenkirchen Munscheidstraße 14 45886 Gelsenkrichen floegel@iat.eu

Prof. Dr. Hans-Martin Zademach Catholic University of Eichstätt-Ingolstadt Ostenstraße 18 85072 Eichstätt zademach@ku-eichstaett.de 